\title{
Experiencing Culture through the Use of Interactive Digital Board
}

\author{
Oluwaoyin Sogbesan \\ City University London \\ Northampton Square \\ London EC1V OHB \\ United Kingdom \\ sogbesantoyin@yahoo.co.uk
}

\section{ABSTRACT}

Within the last twelve years, digital technology and the use of the World Wide Web has significantly influenced and affected daily lives. Revolutionising the way people participate in complex issues as well as how they experience reality. As a result, digital technologies such as interactive exhibits are now commonplace in museum settings, providing 'edutainment' for visitors. However, many technologies co-exist uneasily with more traditional methods of display. This demo seeks to examine how culture can be experienced through interaction between visitors and digital representation through the use of a digital board. Visitors' experience of culture is then explored through an exhibition that provides the audience an opportunity to interact with digitised artefacts. The interactive board is not a move to replace but to complement rather conventional methods of exhibition.

The approach will explore the use of a digital exhibition that provides visitors with the opportunity to interact with cultural objects and leave opinions about the artefacts. Digitisation further influences the way culture is experienced amongst the audience. Consequently, becoming the new instrument for access and preservation of cultures represented. This demo addresses digitisation as the contemporary method for exhibiting and experiencing culture.

Utilising the use of a touch screen board that includes embedded digitally recreated artefacts. A literature review drawing on the works of Geertz (1973/2000), Malraux (1965), Benjamin (1969/1999), Wang (1999), Parry (2010) and Knell (2007) was carried out. The literature review tackles the questions of digitisation, accessibility, and audience experience as it affects traditional cultural artefacts. This study argues that digitisation might be the way forward for curators who constantly seek new ways to engage museum visitors. Considering the notion that digitisation encourages interaction between audience and museum artefacts and not limited to access and preservation alone. Furthermore, audience are not allowed to touch museum exhibit hence only a few objects are allowed at the hands on desk, the demo will be a practical indication that interaction (audience and objects) can leads to audience experience of reality. It is expected that the digital board will not only facilitate audience interaction but will aid audience experience of cultural artefacts in digital format.

\section{REFERENCES}

Benjamin W., (1999) The Work of Art in the Age of Mechanical Reproduction', in Illuminations. Trans. Harry Zohn. London: Pimlico.

Eliot, T. (1949) Christianity and Culture: The ldea of a Christian Society and Notes Towards the Definition of Culture. New York:, Harvest Book.

Fraser, M,, Bowers, J., Brundell, P., O’Malley, C., Reeves, S., Benford, S., Ciolfi, L., Ferris, K., Gallagher, P., Hall, T., Bannon, L., Taxén, G, and Hellström, S., (2004) Re-tracing the Past: Mixing Realities in Museum Settings.

Geertz, C. (1973) The Interpretation of Cultures. New York:, Basic Book Inc., Publishers.

Goodenough, W. (1981) Culture, Language and Society. London: Benjamin/Cummings Publishing.

Hall, S. (1997) Representations: Cultural Representations and Signifying Practices. London: Sage.

Hurcombe, L. (2007) Archaeological Artefacts as Material Culture. London, Routledge. 
Knell, S. (2003), The Shape of Things to Come: Museums in the Technological Landscape, Museum and Society, 11(3):132-144.

Knell, S., MacLeod S., and Watson S. (2007) Museum Revolutions: How Museums Change and are Changed. London: Routledge
Reeves, S., Fraser, M., Schnadelbach, H.,'Malley, C., and Benford, S., (2005) Engaging Augmented Reality in Public Places. Accessed online on 2/2/2012, available at

http://www.cs.bris.ac.uk/ fraser/publications/alt.chi 05/alt.chi05-reeves-et-al.pdf. 